J. Perinat. Med. $10(1982) 34$

\section{Early neurodevelopmental outcome of low birth weight infants surviving neonatal intraventricular hemorrhage*}

\author{
W. Daniel Williamson, Murdina M. Desmond, Geraldine S. Wilson, Leora Andrew, \\ Joseph A. Garcia-Prats
}

From the Sections of Developmental Pediatrics and Neonatology, Department of Pediatrics, Baylor College of Medicine and the Leopold L. Meyer Center for Developmental Pediatrics, Texas Children's Hospital, Houston, Texas

\section{Introduction}

Neonatal intraventricular hemorrhage has emerged as one of the most important and frequently encountered lesions in the central nervous system of the prematurely born infant [1]. Intraventricular hemorrhage is known to contribute significantly to neonatal mortality and morbidity. However, information regarding its effects on the long-term outcome of survivors is limited. This report describes the early neurodevelopmental status of twenty-eight low birth weight infants surviving symptomatic neonatal intraventricular hemorrhage documented by computerized tomography and relates outcome to gestational age and grade of hemorrhage based on severity and location [2].

\section{Subjects and methods}

\subsection{Subjects}

Subjects were low birth weight infants with documented intraventricular hemorrhage (IVH) cared for in the Neonatal Intensive Care Unit (NICU) of Texas Children's Hospital (TCH) between January 1, 1977 and December 31, 1978. Computerized tomography (CT) to diagnose intraventricular hemorrhage was carried out in the presence of the

* This manuscript was presented at the Perinatal Intracranial Hemorrhage Conference December 13, 1980, Washington, D. C.

\section{Curriculum vitae}

W. DANIEL WILLIAMSON, born in 1948, received both his B.S. in education and $M . D$. from Louisiana State University. Following his pediatric training at the Medical University of South Carolina, he had two years of fellowship training in developmental pediatrics with MURDINA M. DESMOND,

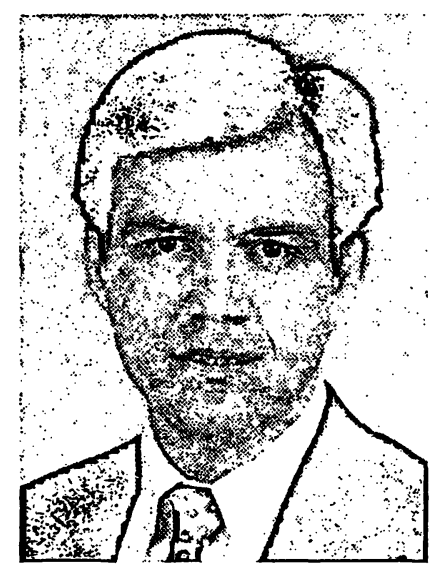
Baylor College of Medicine, Houston. He remains on the faculty there. His major interests include follow-up of premature infants surviving intraventricular hemorrhage and infants with congenital infections, as well as devising educational programs for handicapped children. Dr. WILLIAMSON was the 1978-80 WATCH-Mary Elizabeth Patton Fellow in Pediatrics, Subspecialty Studies, Texas Children's Hospital.

following findings: unexpected fall in hematocrit, tense anterior fontanelle, unexplained deterioration in respiratory or metabolic status, apnea/ bradycardia, change in activity level or tone, seizures, and blood in the cerebrospinal fluid. The routine scanning of all low birth weight infants was not practiced.

During the period covered by this report, the incidence of intraventricular hemorrhage documented by $\mathrm{CT}$ scan in infants of birth weights below 1,500 grams was $41 \%$. The survival rate of all infants with documented IVH was $44 \%$. 
During the study period, thirty-five premature infants weighing less than 2,000 grams surviving IVH confirmed by CT scan were cared for in the NICU. Of the thirty-five, two were excluded from this study because of concomitant congenital infections (rubella, Listeria), three (one severely handicapped) were lost to follow-up after six months because of family relocation and two were not seen following nursery discharge. The remaining twenty-eight children ( $85 \%$ of those eligible) constitute the study group who enrolled for longitudinal follow-up in the Leopold Meyer Center for Developmental Pediatrics, Texas Children's Hospital.

The TCH nursery is a regional referral Level III unit and only three of the study patients were inborn. APGAR scores ranged from 1 to 8 (median 5) at one minute and 4 to 9 (median 6) at five minutes. All infants were initially referred to the NICU for management of respiratory distress. All but one (Patient No. 3) required mechanical ventilation.

The mean gestational age for the group was $\mathbf{2 8 . 9}$ weeks (range 25 to 35 weeks) and mean birth weight was 1,179 grams (range 700 to 1,930 grams). Seventeen infants were male and eleven were female. Paternal social class (HollingsHEAD's classification) [3] was distributed as follows: $27 \%$ - Class II, $31 \%$ - Class III, and $42 \%$ Class IV.

The postnatal age at which in traventricular hemorrhage was clinically suspected ranged from one to ten days. The mean age when computerized tomography was performed to confirm the hemorrhage was six days; all but one infant (Patient No. 17) was scanned at least once during the first fourteen days of life. The extent of hemorrhage on CT scan was graded using the system of PAPILE et al. [2]: Grade I - supependymal hemorrhage, Grade II intraventricular hemorrhage without ventricular dilatation, Grade III - intraventricular hemorrhage with ventricular dilatation, and Grade IV - intraventricular hemorrhage with parenchymal hemorrhage.

\subsection{Methods}

The follow-up consisted of neurologic and developmental assessments done at the ages of three, six, nine, eighteen, and thirty months by a multidisciplinary team. This report describes the findings noted at the patients' visits between thirteen and thirty-four months chronologic age (mean 19.7 months). The outcome categorizations (normal, suspect, abnormal) assigned after these assessments were based on neurologic and developmental functioning.

Neurologic findings classified as suspect included mild disturbances of muscle tone, coordination or motor development, delayed language skills, short attention span or increased motor activity $[4,5]$. Neurologic findings categorized as abnormal were blindness, hearing loss, hydrocephalus, cerebral palsy and seizure disorder.

Developmental performance was assessed utilizing the GeSell Developmental Schedules [6] for infants under eighteen months corrected age or the BAyley Scales of Infant Development [7] for older infants. (Two children were assessed by other measures. See Tab. I.) The Gesell Adaptive Developmental Quotient (DQ) was scaled as follows: 1) normal, $\geqslant 85,2$ ) suspect, 75 to 84 , or $3)$ abnormal, $\leqslant 74$. The BAYLEY Mental Index (MDI) was ranked as follows: 1) normal, $\geqslant 84,2$ ) suspect, 68 to 83 , and 3 ) abnormal, $\leqslant 67$.

A child considered "normal" had a normal neurologic examination as well as a normal developmental assessment for corrected age. The term "multihandicap" indicates the child had both significant developmental delay and abnormal neurologic findings.

\section{Results}

\subsection{Neurologic and developmental status}

Individual clinical findings are summarized in Tab. I.

Cerebral palsy was noted in nine infants (32\%). Seven of these had quadriparesis, one had diplegia, and one had hemiparesis correlating with an area of porencephaly.

Post-hemorrhagic hydrocephalus developed in eight infants. Seven required shunting procedures. (Patient No. 25 developed ventricular dilatation at sixteen months of age, but has not yet required shunting.) Three infants with shunts (Patient No. 17, 22, 24) later demonstrated microcephaly. 
Tab. I. Low birth weight infants surviving IVH: Relation of clinical findings to grade of hemorrhage, birth weight and gestational age.

\begin{tabular}{|c|c|c|c|c|c|c|c|}
\hline $\begin{array}{l}\text { Grade } \\
\text { of IVH }\end{array}$ & $\begin{array}{l}\text { Case } \\
\text { No. }\end{array}$ & $\begin{array}{l}\text { Birth } \\
\text { weight } \\
\text { (Gms.) }\end{array}$ & $\begin{array}{l}\text { Gest. } \\
\text { age } \\
\text { (Weeks) }\end{array}$ & $\begin{array}{l}\text { Age } \\
\text { last seen } \\
\text { (Months) } \\
\end{array}$ & Neurologic findings & $\mathrm{DQ} / \mathrm{MDI}$ & $\begin{array}{l}\text { Outcome } \\
\text { category }\end{array}$ \\
\hline \multirow[t]{2}{*}{ I } & 1 & 700 & 27 & 14 & Blind, spastic quadriparesis & $<50$ & Abnormal $(\mathrm{MH})^{\dagger}$ \\
\hline & 2 & 1510 & 29 & 20 & & 107 & Normal \\
\hline \multirow[t]{12}{*}{ II } & 3 & 1015 & 26 & 21 & & 131 & Normal \\
\hline & 4 & 1060 & 26 & 18 & & 93 & Normal \\
\hline & 5 & 980 & 27 & 15 & Spastic quadriparesis & $<50$ & Abnormal (MH) ${ }^{\dagger}$ \\
\hline & 6 & 800 & 28 & 14 & $\begin{array}{l}\text { Asymmetric tone; delayed } \\
\text { fine motor and language skills }\end{array}$ & 85 & Suspect \\
\hline & 7 & 1260 & 30 & 19 & $\begin{array}{l}\text { Short attention span; delayed } \\
\text { fine motor skills }\end{array}$ & 103 & Suspect \\
\hline & 8 & 1320 & 30 & 20 & $\begin{array}{l}\text { Short attention span; delayed } \\
\text { fine motor and language skills }\end{array}$ & 111 & Suspect \\
\hline & 9 & 1200 & 30 & 13 & & 81 & Suspect \\
\hline & 10 & 1260 & 32 & 20 & $\begin{array}{l}\text { Delayed fine motor and } \\
\text { language skills }\end{array}$ & 97 & Suspect \\
\hline & 11 & 1500 & 32 & 26 & $\begin{array}{l}\text { Hydrocephalus with shunt; } \\
\text { delayed language skills }\end{array}$ & 98 & Abnormal \\
\hline & 12 & 1330 & 31 & 19 & $\begin{array}{l}\text { Hydrocephalus with shunt; } \\
\text { hy pertonic lower extremities }\end{array}$ & 84 & Abnormal \\
\hline & 13 & 1590 & 35 & 21 & & 113 & Normal \\
\hline & 14 & 1360 & 28 & 24 & & 112 & Normal \\
\hline \multirow[t]{6}{*}{ III } & 15 & 700 & 26 & 24 & $\begin{array}{l}\text { Mixed hearing loss; } \\
\text { severe strabismus }\end{array}$ & $<50$ & Abnormal $(\mathrm{MH})^{\dagger}$ \\
\hline & 16 & 1320 & 27 & 34 & $\begin{array}{l}\text { Short attention span; delayed } \\
\text { fine motor skills; poor } \\
\text { balance; toe walking }\end{array}$ & $95^{*}$ & Suspect \\
\hline & 17 & 1330 & 28 & 18 & $\begin{array}{l}\text { Blind; spastic quadriparesis; } \\
\text { hydrocephalus with shunt, } \\
\text { infantile spasms }\end{array}$ & $<50$ & Abnormal $(\mathrm{MH})^{\dagger}$ \\
\hline & 18 & 900 & 28 & 21 & Spastic quadriparesis & 93 & Abnormal \\
\hline & 19 & 1023 & 28 & 25 & $\begin{array}{l}\text { Delayed fine motor skills; mild } \\
\text { hypertonic lower extremities }\end{array}$ & $104 * *$ & Suspect \\
\hline & 20 & 1930 & 34 & 18 & Hydrocephalus with shunt & 100 & Abnormal \\
\hline \multirow[t]{8}{*}{ IV } & 21 & 1320 & 28 & 22 & Spastic diplegia & 108 & Abnormal \\
\hline & 22 & 760 & 25 & 18 & $\begin{array}{l}\text { Blind; spastic quadriparesis; } \\
\text { hydrocephalus with shunt, } \\
\text { infantile spasms }\end{array}$ & $<50$ & Abnormal $(\mathrm{MH})^{\dagger}$ \\
\hline & 23 & 1180 & 27 & 19 & $\begin{array}{l}\text { Blind; quadriparesis, hydro- } \\
\text { cephalus with shunt, infantile } \\
\text { spasms; neurosensory hearing } \\
\text { loss }\end{array}$ & $<50$ & Abnormal $(\mathrm{MH})^{\dagger}$ \\
\hline & 24 & 1070 & 28 & 21 & $\begin{array}{l}\text { Hy drocephalus with shunt; } \\
\text { spastic hemiparesis }\end{array}$ & 56 & Abnormal $(\mathrm{MH})^{\dagger}$ \\
\hline & 25 & 1060 & 30 & 19 & $\begin{array}{l}\text { Arrested hydrocephalus; } \\
\text { generalized seizures }\end{array}$ & 89 & Abnormal \\
\hline & 26 & 1250 & 30 . & 16 & Delayed language skills & 80 & Suspect \\
\hline & 27 & 1360 & $31^{\circ}$ & 14 & & 71 & Abnormal \\
\hline & 28 & 930 & 29 & 19 & Spastic quadriparesis & 50 & Abnormal $(\mathrm{MH})^{\dagger}$ \\
\hline
\end{tabular}

* McCarthy General Cognitive Index

** Stanford-Binet I.Q.

$\mathrm{MH}^{\dagger}$ Multihandicap 


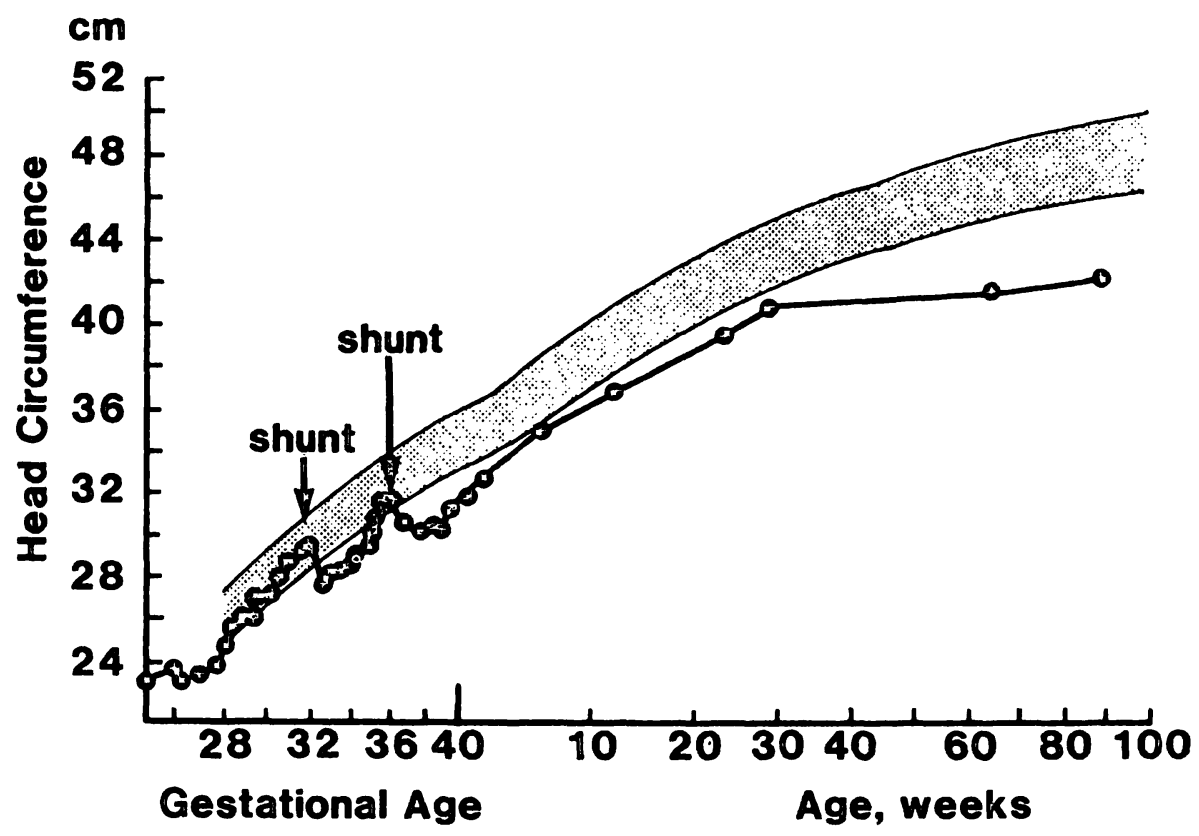

Fig. 1. Measurement of head circumference demonstrating occurrence of microcephaly following post-hemorrhage hydrocephalus in low birth weight infant with Grade III intraventricular hemorrhage (Patient No. 22) [13a].

The occurrence of microcephaly in a patient with earlier, shunted post-hemorrhagic hydrocephalus is illustrated by the head circumference curve of Patient No. 22 (Fig. 1). Three of the eight with hydrocephalus had no other major neurologic or developmental abnormalities, and a fourth had a generalized seizure disorder but normal development. The remaining four infants with hydrocephalus were multihandicapped. Three of these developed infantile spasms beginning at five, eight and nine months chronologic age.

Neurosensory deficits included blindness secondary to cicatricial retinopathy of prematurity in four infants and hearing loss in two. (One infant was both deaf and blind.)

Seventeen patients (61\%) had developmental quotients within the normal range and two (7\%) in the suspect range. Nine (32\%) showed delayed development; eight of these were multihandicapped.

On the basis of both neurologic examination and developmental testing, five infants were considered normal and eight suspect (Tab. II). Fifteen infants were abnormal; eight of these were multihandicapped.

\subsection{Social and economic impact}

The stresses experienced by the families during the followup period were intense and cumulative.
Tab. II. Short term outcome related to grade of IVH in 28 low birth weight infants assessed at mean age of 19.7 months.

\begin{tabular}{lcccccc}
\hline Outcome & \multicolumn{3}{l}{ No. patients } & & \multicolumn{2}{c}{$\begin{array}{c}\text { Total Per- } \\
\text { No. }\end{array}$} \\
\cline { 2 - 6 } & Grade IVH & \multicolumn{2}{c}{ cent } \\
& I & II & III & IV & & \\
\hline Normal & 1 & 4 & 0 & 0 & 5 & $18 \%$ \\
Suspect & 0 & 5 & 2 & 1 & 8 & $28 \%$ \\
Abnormal & 1 & 3 & 4 & 7 & 15 & $54 \%$ \\
(Multi- & $(1)$ & $(1)$ & $(2)$ & $(4)$ & $(8)$ & $(28 \%)$ \\
handicap) & & & & & & \\
\hline Total & 2 & 12 & 6 & 8 & 28 & \\
\hline
\end{tabular}

They appeared related to many factors, i.e. the early birth, the prolonged nursery stay (mean 74 days, range 42-141), the many medical problems following nursery discharge and the high costs of nursery hospitalization (initial costs ranging from $\$ 25-125,000)$. Subsequent rehospitalizations were not uncommon - to date sixteen of the twenty-eight infants have required thirty-three rehospitalizations.

The impact of these survivors on the community may be illustrated by the referral during infancy of thirty-six percent (ten of twenty-eight) of the study population to intervention programs in community agencies. These infants will also 
qualify for special education in public school at age three in accordance with Public Law 94-142 (Education for All Handicapped Children's Act) [8].

\subsection{Clinical correlations}

In this study, two findings were significant. First, the incidence of abnormal outcome was significantly higher among infants with Grade III or IV hemorrhage (79\%) than among infants with Grade I or II hemorrhage $(29 \%)\left(\mathrm{X}^{2}\right.$ with Yates correction $=5.166 ; .01<P<.025)$. Second, the mean gestational age of the eight multihandicapped infants (27.0 weeks) was significantly less than that of the remaining twenty infants (29.7 weeks) (STuden T's $t$ Test: $t=3.754 ; .001<\mathrm{P}<$ .01 ; two-tailed significance level).

The incidence of abnormal outcome in infants with birth weights below 1,000 grams was high $(86 \%)$ regardless of grade of hemorrhage. $\mathbf{A b}$ normal outcome for infants with birth weights greater than 1,000 grams appeared to be more directly related to the grade of hemorrhage than to birth weight. (Abnormal outcome in infants with birth weight greater than 1,000 grams: $0 \%$ (0/1) Grade I, 20\% (2/10) Grade II, 50\% (2/4) Grade III, $83 \%$ (5/6) Grade IV.) These trends could not be statistically correlated because of the small sample size.

\section{Discussion}

Although intraventricular hemorrhage is generally considered to be a major contributor to the neonatal morbidity and mortality of very low birth weight infants, its specific association with outcome in survivors is only sparcely documented in the literature $[9,10]$. The single detailed report on early outcome related to grade of hemorrhage appearing in the literature to date is that of KRISHNAMOORTHY et al. [9], who report a series of fifteen infants, eighty percent of whom had lesser degrees of hemorrhage (Grade I or II). The mean gestational age for the group was 32 weeks. Our study group, in contrast, is equally divided between those with severe hemorrhage (Grades III/IV) and those with less severe grades (Grades I/II) and has a lower mean gestational age (28.9 'weeks).

In the present study, infants with Grades I and II hemorrhage had significantly better early outcome than those with Grade III or IV hemorrhage, a finding consistent with that of KRISHNAMOORTHY. Our study indicates that poorest outcome (multihandicapped status) is also related to extreme prematurity (gestational age $\leqslant 27$ weeks).

Four clinical findings in this study are of special note. First, the outcome of infants with posthemorrhagic hydrocephalus appeared more directly related to gestational age and to initial grade of hemorrhage than to the presence or absence of hydrocephalus itself. Second, head growth diminished rapidly in three patients who had earlier shunted hydrocephalus, with the eventual development of microcephaly. Third, blindness secondary to cicatricial retinopathy of prematurity (ROP) occurred in $14 \%$ of our patients, a high incidence for low birth weight infants in general [11]. An association between cicatricial ROP and IVH has been suggested, which may account for the high incidence noted in this study [12]. Fourth, infantile spasms emerged during the follow-up period in three of our patients, a finding not previously reported in IVH survivors. Since each infant was of low birth weight and experienced significant perinatal asphyxia (factors previously considered predisposing to infantile spasms) [13], a direct association between IVH and infantile spasms cannot be presumed.

Although forty-six percent of the study group were categorized as normal or suspect and did not demonstrate static abnormalities when last evaluated, they will remain at risk for perceptualmotor deficits, motor clumsiness, and disorders of attention, learning/language, and behavior [1418]. It is possible that these disorders, which reportedly have a high incidence in premature infants, may in part be residua related to the occurrence or secondary effects of earlier intraventricular hemorrhage. Only the long-term follow-up of survivors can clarify this point. 
Summary

This article reports the follow-up findings in $\mathbf{2 8}$ pre-term infants who survived symptomatic neonatal intraventricular hemorrhage and were cared for in the Neonatal Intensive Care Unit of Texas Children's Hospital, Houston. The severity of hemorrhage noted on CT scan was graded using the system of PAPILE, et al. [2].

The mean gestational age for the group was 28.9 weeks (range 25 to 35 weeks) and mean birth weight was 1,179 grams (range 700 to 1,930 grams). Seventeen infants were male and eleven were female. Paternal social class (HOLLINGSHEAD's classification) was distributed as follows: $27 \%$ class II, $31 \%$ class III, and $42 \%$ class IV.

Follow-up consisted of neurologic examination and multidisciplinary developmental assessment. The outcome categorizations (normal, suspect, abnormal) were based on both neurologic and developmental functioning. A child considered "normal" had a normal neurologic examination and developmental function within the normal range for corrected age. The term "multihandicapped" indicated both significant developmental delay and abnormal neurologic findings.

At a mean age of 19.7 months, five infants were considered normal (18\%), eight suspect $(28 \%)$, and fifteen abnormal (54\%). (Tab. II). Eight abnormal infants were multihandicapped. Cerebral palsy was noted in nine infants (32\%). (Tab. I). Post-hemorrhagic hydrocephalus was noted in eight; seven required shunting. Three infants with shunts later demonstrated microcephaly. (Fig. 1). Three developed infantile spasms. Neurosensory deficits included blindness (secondary to cicatricial retinopathy of prematurity) in four infants and hearing loss in two. At least one-third of the study group will require special education by age three years.

Two significant findings emerged in this study. First, the incidence of abnormal outcome was higher among infants with Grades III and IV hemorrhage (79\%) than among infants with Grades I or II hemorrhage $(29 \%)(.01<\mathrm{P}<$ $.025)$. Second, the mean gestational age of the eight multihandicapped infants (27.0 weeks) was significantly below that of the remaining twenty infants (29.7 weeks) $(.001<\mathrm{P}<.01)$.

Although forty-six percent of the study group did not have static abnormalities when evaluated, they remain at risk for disorders of language, learning and behavior. Longterm follow-up of these infants is planned to determine if these disorders may, in part, be related to the occurrence or secondary effects of earlier intraventricular hemorrhage.

Keywords: Infantile spasms, intraventricular hemorrhage, very low birth weight infants.

\section{Zusammenfassung}

Neurologische Komplikationen und Entwicklungsstörungen bei Kindern nach überlebter neonataler Ventrikelblutung

Wir berichten über die Nachuntersuchungen an 28 Frïhgeborenen, die eine neonatale Ventrikelblutung überlebten und in der Intensivüberwachungseinheit des Texas

Children's Hospital, Houston, behandelt wurden. Der Umfang der Ventrikelblutung wurde computertomografisch festgestellt und nach dem Schema von PAPILE et al. klassifiziert [2].

Das mittlere Gestationsalter in dieser Gruppe lag bei 28.9 Wochen ( 25 bis 35 Wochen), das mittlere Geburtsgewicht bei $1179 \mathrm{~g}$ (700 bis $1930 \mathrm{~g}) .17$ Kinder waren männlich, 11 weiblich. Die Aufteilung in soziale Klassen nach HOLLINGSHEAD ergab: Klasse -II 27\%, Klasse III $31 \%$, Klasse IV $42 \%$.

Die Nachuntersuchung bestand aus neurologischen Prüfungen und multidisziplinären Entwicklungstesten. Bei der Kategorisierung (unauffällig, suspekt, auffällig) wurden sowohl die neurologischen Befunde wie auch die Ergebnisse aus den Entwicklungstesten zugrunde gelegt. Ein als ,normal' eingestuftes Kind hatte einen unauffälligen neurologischen Status und befand sich entwicklungsmäßig innerhalb der normalen Streubreite einer auf sein Alter bezogenen Vergleichsgruppe. Eine Mehrfachbehinderung diagnostizierten wir, wenn sowohl eine signifikante Entwicklungsverzögerung wie auch ein auffälliger neurologischer Status vorlagen.
Mit einem mittleren Alter von 19.7 Monaten wurden 5 Kinder $(18 \%)$ als unauffällig, $8(28 \%)$ als suspekt und $15(54 \%)$ als auffällig eingestuft (Tab. II). Bei 8 Kindern lag eine Mehrfachbehinderung vor, bei 9 Kindern (32\%) eine Cerebralparese (Tab. I). 8 Kinder zeigten einen posthämorrhagischen Hydrocephalus, 7 von ihnen brauchten einen Shunt. Hiervon hatten 3 später einen Mikrocephalus (Fig. 1). Bei 3 Kindern entwickelten sich Spasmen.

An neurosensorischen Störungen fand sich bei 4 Kindern eine Amaurosis infolge der narbigen Retinopathie und Gehörverlust bei 2 Kindern. Schließlich benötigte ein Drittel unser Untersuchungsgruppe eine spezielle erzieherische Betreuung ab dem 3. Lebensjahr. Unsere Untersuchung zeigt 2 bedeutsame Fakten:

1. Unter den Kindern mit Hämorrhagien vom Typ III und IV war die Komplikationsrate mit $79 \%$ wesentlich höher als in der Gruppe mit Hämorrhagien vom Typ I und II, wo sie bei $29 \%$ lag $(0.01<p<0.025)$.

2. Das mittlere Gestationsalter bei den 8 mehrfach Behinderten lag mit 27 Wochen deutlich unter dem mittleren Gestationsalter der übrigen 20 Kinder, das mit 29.7 Wochen anzugeben ist $(0.001<\mathrm{p}<0.01)$. Auch wenn $46 \%$ der Kinder zum Untersuchungszeitpunkt keine statomotorischen Auffälligkeiten zeigten, tragen sie ein hohes Risiko, Sprach-, Lern- und Verhaltensstörungen zu entwickeln. Eine Langzeituntersuchung ist geplant, um letztlich bestimmen zu können, ob die Störungen als direkte Folge der Ventrikelblutung oder als sekundäre Effekte des Traumas anzusehen sind.

Schlïsselwörter: Niedriges Geburtsgewicht, Spasmen im Kindesalter, Ventrikelblutung. 


\section{Résumé}

Etude du développement neurologique précoce, d'enfants prématurés ayant survécu à une hémorrhagie intraventriculaire néonatale

Cet article donne les résultats étudiés de 28 enfants prématurés ayant survécu une hémorrhagie intraventriculaire néonatale ayant été traités dans le "Neonatal Intensive Care Unit of Texas Children's Hospital à Houston." La séverité de l'hémorrhagie vue sur le CT scan était évaluée selon le système de PAPILE et al. [2]. La durée moyenne de la grossesse pour ce groupe était de 28,9 semaines (compris entre 25 et 35 semaines) et le poids moyen à la naissance de 1,179 grammes (s'étalant de 700 à 1,930 gr.) 17 enfants était de sexe mâle et 11 de sexe femelle.

Les classes sociales (selon la classification de HOLLINGSHEAD s'établissaient comme suit: $27 \%$ de classe II, $31 \%$ de classe III et $43 \%$ de classe IV.

Les examens de contrôle consistaient en tests neurologiques, et une évaluation du développement par methodes multidisciplinaires.

La catégorisation (normal, suspect, anormal) était basée sur le fonctionnement neurologique et le développement. Pour un enfant soit considéré comme normal il devait avoir un examen neurologique normal et un développement correspondant aux normes corrigées en fonction de son âge. Le terme plurihandicapé signifait un développement retardé et un examen neurologique anormal. A l'âge de 19,7 mois, 5 enfants furent considérés comme normaux (18\%), 8 comme suspects $(28 \%)$ et 15 comme anormaux (54\%) (Tab. II). 8 enfants anormaux étaient plurihandicapés. La paralysie cérébrale (CP) fut constatée dans le cas de 9 enfants (32\%) (Tab. 1). Une hydrocéphalie post-hémorrhagique fut constatée dans 8 cas dont 7 requirent un pontage. Trois enfants avec pontage présentèrent plus tard une microcéphalie (Fig. 1). 3 ont développé des spasmes infantils. Des déficits neuro-sensitifs, comprenant la cécité (suite à une rétinopathie cicatricielle du prématuré) se sont développées chez 4 enfants et la surdité chez 2 enfants. Au moins un tiers de ces enfants auro besoin d'une éducation spéciale à l'âge de 3 ans. Deux faits remarquables émergent de ette étude.

1: L'incidence de résultats anormaux étaient plus élevée dans le cas d'hémorrhagie des enfants issus des groupes III et IV $(79 \%)$ que ceux des groupes I et II $(29 \%)(0,01$ < $\mathrm{p}<0,025)$

2: la durée moyenne de la grossesse de 8 enfants plurihandicapés (27 semaines) était significativement plus basse que celle des 20 autres $(29,7$ semaines) $(0,001<$ p $<0,01$ ). Parmi les $46 \%$ qui ne présentaient pas d'anomalies statiques lors de l'examen, subsiste le risque de présenter des désordres du langage, de la faculté d'apprendre et des troubles du comportement.

Une surveillance à long terme de ces enfants est prévue pour déterminer si ces désordres peuvent, en partie, être reliés à l'apparition des éffets secondaires d'une hémorrhagie intraventriculaire précoce.

Mots-cles: Enfants prématurés, hémorrhagie intraventriculaire, spasmes infantiles.

Acknowledgements: The authors thank Doctor L. PAUL GERSON, Neuroradiologist, Texas Children's Hospital, for grading the CT scans. We express appreciation to the Meyer Center staff, particularly SUSAN THURBER, LYNDA ARMSTRONG, and SHIRLEY NORTHROP, for their participation, to EVELYN KROULIK, PHYLLIS GUTIERREZ, and BARBARA NASH for preparation of this manuscript and to Doctors ALAN PERCY, JANICE GODDARD and MARVIN FISHMAN for manuscript review.

This work was supported by grants from the LILLIAN KAISER LEWIS FOUNDATION, the HAMMAN FOUNDATION, the MCASHAN FUND, and MCT No. 000,436.

\section{Bibliography}

[1] AMIEL-TISON, C.: A method for neurological evaluation within the first year of life: Experience with fullterm newborn infants with birth injury. In: Ciba Foundation Symposium No. 59, Major mental handicap: Methods and costs of prevention. Excerpta Medica, Amsterdam 1979

[2] BAYLEY, N.: Bayley scales of infant development manual. Psychological Corporation, New York 1979

[3] DE HIRSCH, K., J. JANSKY, W. LANGFORD: Predicting reading failure. Harper and Row, New York 1966

[4] Desmond, M. M., G. S. Wilson, E. J. ALT, E. S. FISHER: The very low birth weight infant after discharge from intensive care: Anticipatory health care and developmental course. Current Problems in Pediatrics X (6), (1980)
[5] DRILLIEN, C. M.: Abnormal neurologic signs in the first year of life in low birth weight infants: Possible prognostic significance. Dev. Med. Child. Neurol. 14 (1972) 575

[6] DRILliEN, C. M., A. J. M. TOMSON, K. BURGOYNE: Low birth weight children at early school age: A longitudinal study. Dev. Med. Child. Neurol. $22(1980) 26$

[7] The Education for All Handicapped Children Act of 1975, Public Law 94-142: 2OUSC 1401 et seq: Federal Register 42 (163): 42474-42518, August 23, 1977

[8] FRANCIS-WilliamS, J., P. A. DAVIES: Very low birth weight and later intelligence. Dev. Med. Child. Neurol. 15 (1973) 447

[9] HOLLINGSHEAD, A. B.: Two factor index of social position. New Haven, Connecticut 1957 
[10] KNOBLOCH, H., B. PASAMANICK: Gesell and Amatruda's developmental diagnosis: The evaluation and management of normal and abnormal neuropsychologic development in infancy and early childhood. Ed 3. Harper and Row, Hagerstown-Maryland 1974

[11] KRISHNAMOORTHY, K. S., D. C. SHANNON, G. R. DE LONG: Neurologic sequelae in the survivors of neonatal intraventricular hemorrhage. Pediatrics 64 (1979) 233

[12] LACY, J. R., J. K. PENRY: Infantile spasms. Raven Press, New York 1976

[13] MCCORMICK, A. Q.: Retinopathy of prematurity. Current Problems in Pediatrics VII (11) (1977)

[13a] NELLHAUS, G.: Composite international and interracial graphs. Pediatrics 41 (1968) 106

[14] PAPE, K. E., J. S. WIGGLESWORTH: Haemorrhage, ischemia and the perinatal brain in Clinics in Developmental Medicine Nos. 69/79, Spastics International Publications, William Heinemann Medical Books, London 1979
[15] PAPIle, L. A., J. BURSTEIN, R. BURSTEIN, H. KOFFLER: Incidence and evolution of subependymal and intraventricular hemorrhage: A study of infants with birth weights less than 1,500 grams. J. Pediat. 92 (1978) 529

[16] PAPILE, L. A., G. MUNSICK, N. WEAVER, S. PECHA: Cerebral intraventricular hemorrhage (CHV) in infants less than 1,500 grams: Developmental follow-up at one year. Pediat. Res. 13 (4) (1979) 527

[17] PROCIANOY, R. S., J. A. GARCIA-PRATS, H. M. HITTNER: An association between retinopathy of prematurity and intraventricular hemorrhage in very low birth weight infants. Acta Scand. Pediat. (in press)

[18] WEINER, G., R. V. RIDER, W. C. OPPEL, P. A. HARPER: Correlates of low birth weight, psychological status at eight to ten years of age. Pediat. Res. $2(1968) 110$

Received and accepted August 4, 1981.

W. Dañiel Williamson, M. D.

Meyer Center for Developmental Pediatrics Texas Children's Hospital

Houston, Texas 77030/USA 